VOLUME 58 ISSUE 12020

\title{
INTERNATIONAL ANNALS OF CRIMINOLOGY
}

\section{ANNALES INTERNATIONALES DE CRIMINOLOGIE}
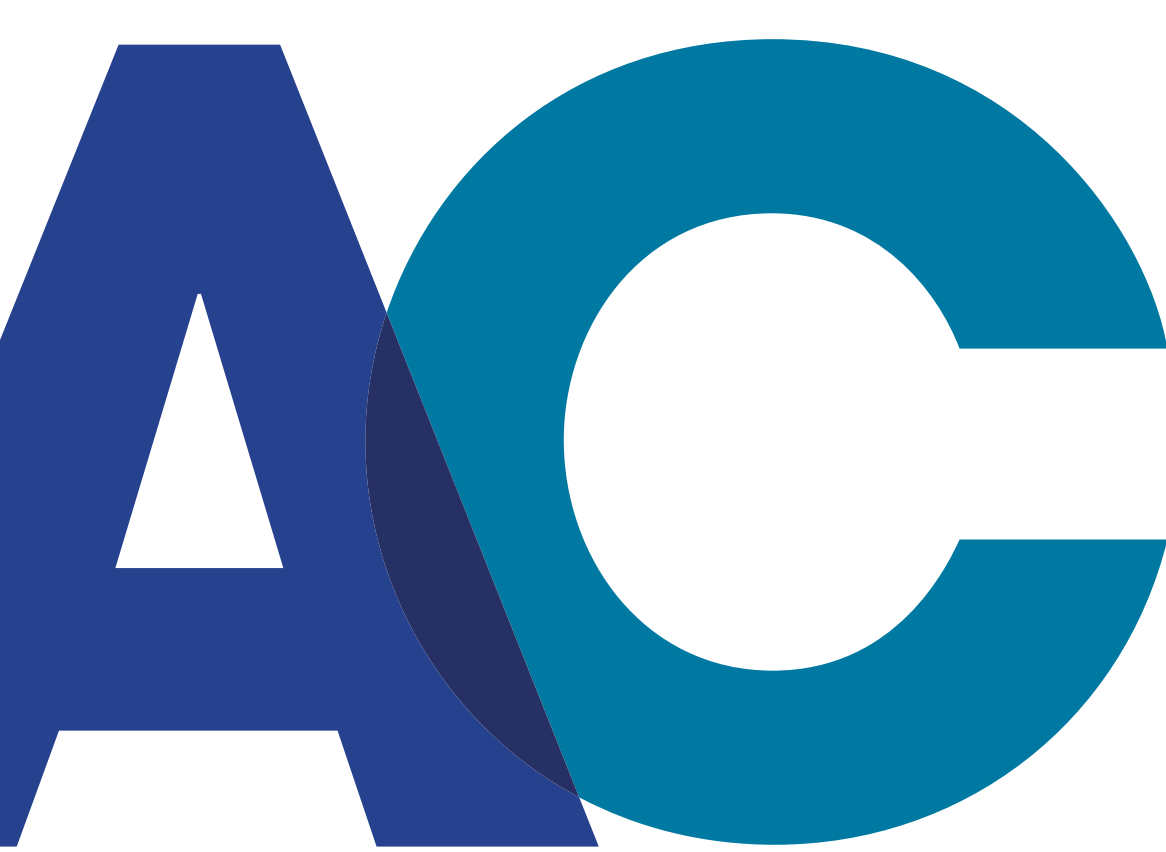
International Annals of Criminology

Annales Internationales de Criminologie

Anales Internacionales de Criminología

\section{犯罪学国际年刊}

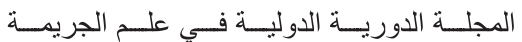

The International Annals of Criminology is an international and multidisciplinary journal devoted to the study of crime and crime prevention. Published by the International Society of Criminology, the Annals is one of the oldest continuously published scholarly journals in the area of criminology. Its mission is to further the dissemination of original international material on criminology and criminal justice, with a particular focus on different contexts beyond Europe and North America. The Annals welcomes contributions relating to crime, cybercrime, crime prevention, criminal law, medico-legal subject matters, and the administration of criminal justice and provides a platform for learning, debate, and collaboration among criminologists, policy makers, professionals, and practitioners worldwide.

\section{Editor in Chief}

Emilio C. Viano

International Society of Criminology

\section{Editorial Board}

Uju Agomoh

Prisoners Rehabilitation \&

Welfare Action, Enugu, Nigeria

John Braithwaite

Australian National University,

Australia

Santiago Redondo Illescas

University of Barcelona

Catalonia, Spain

Georges Kellens (emeritus), Université de Liège, Belgium

Jianhong Liu

University of Macau, China
Mohamed Y. Mattar,

Qatar University

Setsuo Miyazawa

University of California, Hastings

Shiroma Jeeva Shiranje Niriella

University of Colombo, Sri Lanka

Sanjeev P. Sahni

O.P. Jindal University, India

Jerzy Sarnecki

Stockholm University, Sweden

Lawrence Sherman

Cambridge University, UK

Wesley Skogan

Northwestern University, USA
Jeremy Travis

The Laura and John Arnold

Foundation, New York

Sandra Walklate

Liverpool University, UK

David Weisburd

Hebrew University, Israel and

George Mason University,

USA

Raul Zaffaroni

Inter American Court of Human

Rights, San Jose, Costa Rica

A special thanks to the distinguished Colleagues who have generously accepted to review and evaluate materials or translations for publication in this volume of the International Annals of Criminology.

Material for publication in the Annals is invited and welcomed. Prepare your article following the instructions available at https:/www.cambridge.org/core/journals/international-annals-of-criminology/ information/instructions-contributors. Please use 12 point Times New Roman, double spaced. Length limit: 20,000 words. DOCX format preferred. Tables and figures in color incur a publisher's fee. Send proposals and/ or your work to iscpublish@gmail.com.

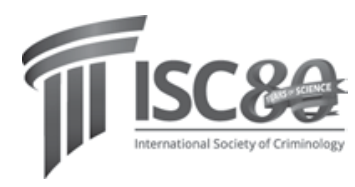

The International Annals of Criminology is published by Cambridge University Press on behalf of the journal of the International Society of Criminology. For more information please visit https://intercrim.com or write to: iscpublish@gmail.com

ISSN: $0003-4452$

E-ISSN: 2398-676X

(C) International Society of Criminology 2020 